\title{
Tumorigenicity of Esophageal Cancer Stem Cells (ECSCs) in nude mouse xenograft model
}

\author{
Ayyoob Khosravi ${ }^{1,2}$, Fariba Kokabi ${ }^{3}$, Ramezan Behzadi ${ }^{4}$, Jahanbakhsh Asadi ${ }^{3 *}$
}

1. Stem Cell Research Center, Golestan University of Medical Sciences, Gorgan, Iran.

2. Department of Molecular Medicine, Faculty of Advanced Medical Technologies, Golestan University of Medical Sciences, Gorgan, Iran.

3. Metabolic Disorders Research Center, Golestan University of Medical Sciences, Gorgan, Iran.

4. North Research Centre, Pasteur Institute of Iran, Amol, Iran.

Article Type:

Original Article

\section{Article History:}

Received: 9 May 2019

Revised: 18 Jun 2019

Accepted: 26 Aug 2019

\section{*Correspondence:}

Jahanbakhsh Asadi, Metabolic Disorders Research Center, Golestan University of Medical Sciences, Gorgan, Iran dr.asadi@goums.ac.ir

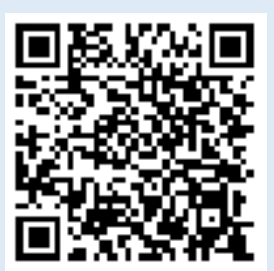

\begin{abstract}
Background and objectives: Modeling cancer in vivo is a very important tool to investigate cancer pathogenesis and molecular mechanisms involved in cancer progression. Laboratory mice are the most common animal used for rebuilding human cancer in vivo. Cancer stem cells (CSCs) are the main reason of failure in cancer therapy because of tumor relapse and metastasis. Isolation of cancer stem cells helps us to study their function and behavior. In the current study we separate cancer stem-like cells using sphere formation assay then investigate their tumorigenicity in xenograft tumor model.

Methods: YM1 cancer cells were cultured in serum-free media (SFM) in low adherent culture dishes for enrichment of cancer stem cells. The resulting spheres containing cancer stem-like cells were dissociated into single cells and were injected into the dorsal flank of B6 nude mice.

Results: A few days after injection, subcutaneous tumors formed. The growth curves of the resulting tumors were plotted using their weekly recorded lengths. The tumors' volume and weight were measured. The size of resulting tumors was appropriate to the number of cells injected. Pathological analysis confirmed esophageal origin of the resulting tumors.

Conclusion: Using laboratory mice models is a practical modeling system that provides us investigation of human tumors pathogenesis in vivo.
\end{abstract}

Keywords: Cancer stem cell, ESCC, Xenograft mouse model

Copyright $\subseteq$ 2018, Jorjani Biomedicine Journal has published this work as an open access article under the terms of the Creative Commons Attribution License (http://creativecommons.org/licenses/by-nc/4.0/) which permits noncommercial uses of the work while it is properly cited. 


\section{Introduction}

Esophageal cancer is the 8th most common type of cancer with two main histological subtypes: esophageal squamous cell carcinoma (ESCC) and esophageal adenocarcinoma $(1,2)$. ESCC is the major subtype which comprises $\% 80$ of cases in the world (3). More than $50 \%$ of patients with esophageal cancer present with cancer metastasis and 5-year-survival rate of patients with ESCC is only $15 \%$ to $25 \%(4,5)$. Although human tumor cell lines have increased our knowledge about cancer pathogenesis studying these cell lines in vitro has some drawbacks that originate from the different environments which cells are exposed to in vitro and in vivo. In human body the tumor cells growth and maintenance are affected by different types of stromal cells. The cells are in a three dimensional structure with vascular and immune systems which are in direct communication with them. Furthermore the tumor cells in vitro are subjected to genetic alteration due to multiple passages. These all lead to changes in tumorigenicity mechanisms in cultured tumor cells which for example cause different drug efficacy results between the treated cells in vitro and the patients (6). Modeling tumorigenesis in laboratory animals allows us to study tumors in vivo and makes it possible to isolate the tumors in all stages and study them pathologically, biochemically and genetically. Animal models are important preclinical tools to evaluate and test new cancer therapies (7). Several types of animals are used in cancer research including zebrafish (8), mice (9), rats (10), rabbits (11), and monkeys (12) which among them mice are the most commonly used animals. To make laboratory animal models transplantation of tumor cells into animals and production of genetically engineered mice are mostly used (7). In xenograft transplantation assay human tumor cells are injected into murine host with a compromised immune system (e.g. Nude mice) to prevent human cells rejection (13).

Cancer stem cells (CSCs) are a small subpopulation of cancer cells within the bulk of the tumor. These cells are first recognized in leukemia (14) and after that isolated from solid tumors such as breast (15), brain (16), colon (17), ovary (18) and pancreas(19). CSCs are thought to be the origin of most human tumor types and the main reason of treatment resistance, tumor relapse, and metastasis (20). Owing to the absence of unique cell surface markers and distinct morphology, CSCs are studied based on their functionality (21). In sphere formation assay, which is a marker independent method, tumor cells are cultured in serum-free medium on low adherent plates. These circumstances exert particular stress on cells. The normal differentiated cells, which must adhere to a matrix to survive, die but cancer stem-like cells persist, divide and form three dimensional spheres (22). In the current study, we aimed to monitor cancer stem cells tumorigenicity using xenograft mouse models.

\section{Materials and Methods}

\section{Cell line and culture protocol}

We used YM1 esophageal cancer cells developed from a 50-year-old Iranian woman (Turkmen race) with esophageal squamous cell carcinoma (ESCC) (23). We cultured cells in DMEM-F12 (GIBCO) medium which was supplemented with $10 \%$ fetal bovine serum (FBS) (GIBCO) and 100 units $/ \mathrm{ml}$ penicillin and $100 \mu \mathrm{g} / \mathrm{ml}$ streptomycin 
(BIOIDEA). The adherent cells were passaged and maintained in $\mathrm{CO} 2$ incubator at $37{ }^{\circ} \mathrm{C}$. After a few passages the adherent cells were cultured in DMEM-F12 medium supplemented with 5\% FBS to become adapted to serum-free medium used in sphere formation assay.

\section{Sphere formation assay}

The adherent cells were detached and washed with phosphate-buffered saline (PBS ) and were suspended in low adherent $6 \mathrm{~mm}$ Petri dishes (Labtron) containing $3 \mathrm{ml}$ serum-free medium consists of DMEM/F12, $100 \mathrm{IU} / \mathrm{ml}$ penicillin, $\quad 100 \quad \mu \mathrm{g} / \mathrm{ml}$ streptomycin(BIOIDEA), $20 \mathrm{ng} / \mathrm{ml}$ human recombinant epidermal growth factor (hrEGF), $20 \mathrm{ng} / \mathrm{ml}$ human recombinant basic fibroblast growth factor (hrbFGF)(ROYAN) and 2\% B27 supplement (GIBCO) at a density of 50000 cells $/ \mathrm{ml}$. The Petri dishes were maintained in $\mathrm{CO} 2$ incubator at $37{ }^{\circ} \mathrm{C}$. After the formation of the spheres, they should be passaged. Otherwise, their diameter exceeds $60 \mu \mathrm{m}$ and central cells die from the lack of nutrients and peripheral cells will differentiate. The spheres were collected by slow centrifugation and dissociated with trypsin-EDTA and pipetage. Then the single cells were centrifuged to eliminate the enzyme and cultured in serum-free medium again.

\section{Xenograft transplantation assay}

After three passages, the resulting spheres were dissociated using trypsin and washed with PBS. Then the specific number of single cells in a final volume of $300 \mu \mathrm{l}$ of PBS/ Matrigel mixture (1:1 volume) was injected subcutaneously into the dorsal flank of 4week-old B6 nude mice (Table1). After detection of first tumors, their sizes were measured once a week using the caliper and their volumes were measured using $\pi / 6 \times \mathrm{L} \times \mathrm{W} \times \mathrm{H}$ formula (24). 48 days after injection mice were sacrificed and the tumors were removed and weighed by a digital balance.

Table1. The number of cancer stem cells used for subcutaneous injection into three nude mice

\begin{tabular}{|c|l|l|l|}
\hline & Mouse1 & $\begin{array}{l}\text { Mouse } \\
2\end{array}$ & Mouse 3 \\
\hline $\begin{array}{l}\text { The number of cells in 150 } \\
\mu 1 \text { PBS }\end{array}$ & $\begin{array}{l}4 \times 10^{6} \\
\text { cells }\end{array}$ & $\begin{array}{l}4 \times 10^{5} \\
\text { cells }\end{array}$ & $\begin{array}{l}4 \times 10^{4} \\
\text { cells }\end{array}$ \\
\hline Matrigel & $150 \mu \mathrm{l}$ & $150 \mu \mathrm{l}$ & $150 \mu \mathrm{l}$ \\
\hline
\end{tabular}

\section{Results}

We used the sphere formation assay to isolate cancer stem cells (Figure1).
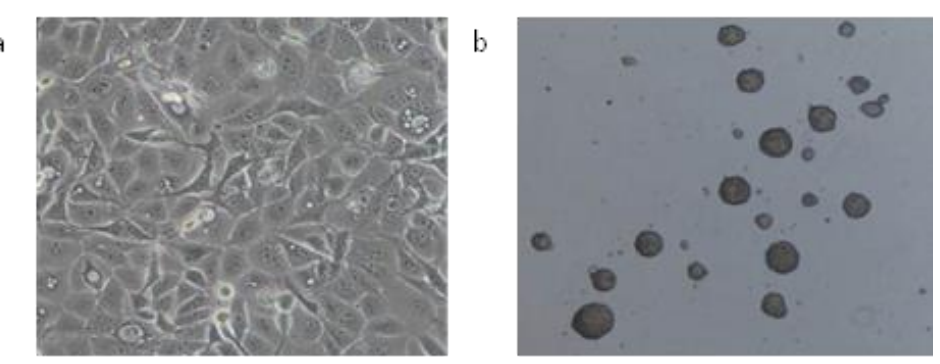

Figure1: a The adherent cells $(20 \times 10)$ b spheres $(10 \times 10)$. The adherent cells were passaged in serum free medium on low adherent dishes and three dimensional spheres formed. 
Then we used in vivo xenograft transplantation assay to investigate the ability of these cancer stem cells to form subcutaneous tumors in nude mice. The Length (the longest dimension), width (the distance perpendicular to and in the same plane as the length) and height (diameter of the tumor perpendicular to the length and width) of each tumor was measured with caliper once a week (Figure2, Table2).

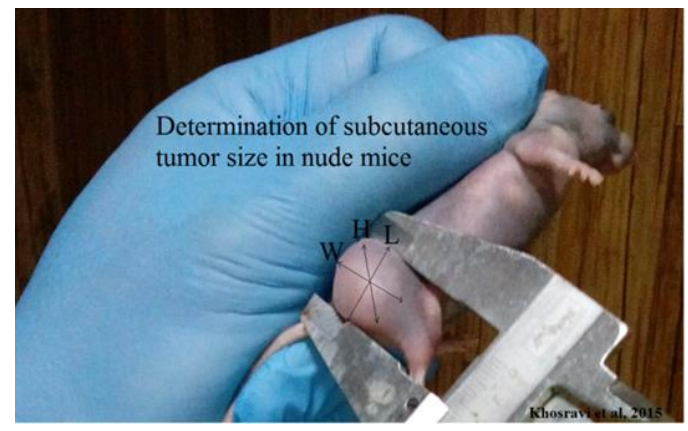

Figure2. Illustration of the method used to measure the tumor size. The tumor length, width and height were measured once a week using a caliper.

The tumor growth curve of each tumor was plotted with Excel software using the recorded length of them. In these growth curves the horizontal axis is based on day and the vertical axis is based on tumor length in cm (Figure3).

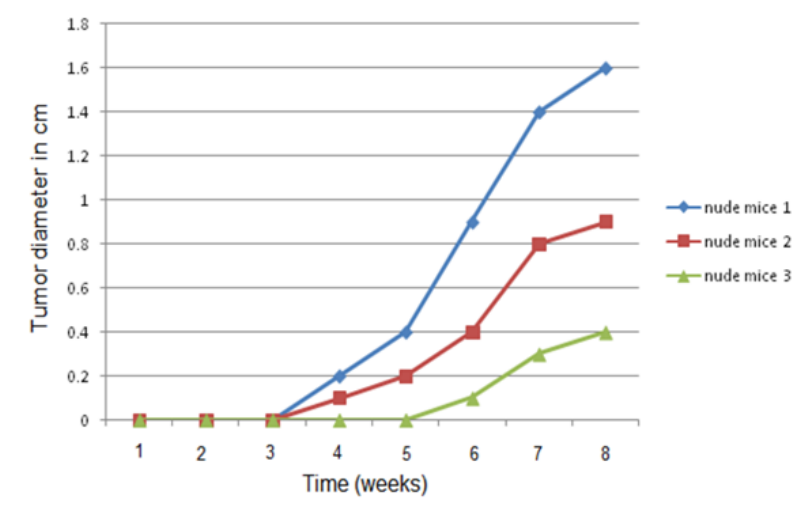

Figure3. The tumors growth curves. The tumor growth curve of each tumor was plotted using the recorded length of the tumors

We measured the size of the three tumors before and after dissection and calculated their volumes with the $\pi / 6 \times \mathrm{L} \times \mathrm{W} \times \mathrm{H}$ formula (Figure4, Table3).
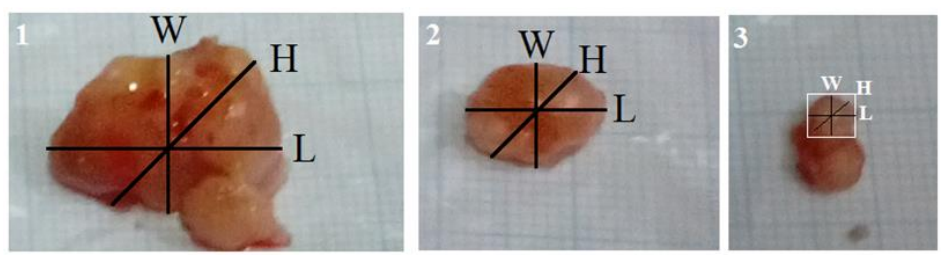

Figure4. The measurement of the tumors' sizes after dissection. To calculate the volumes of the tumors, their sizes were measured before and after dissection.

Table2. The recorded size of tumors measured once a week

\begin{tabular}{|l|l|c|c|c|c|c|}
\hline $\begin{array}{l}\text { Nude } \\
\text { mouse }\end{array}$ & $\begin{array}{l}\text { The } \\
\text { number of } \\
\text { injected } \\
\text { cells }\end{array}$ & $\begin{array}{l}\text { tumor size } \\
\text { in } 3^{\text {rd }} w e e k\end{array}$ & $\begin{array}{l}\text { Tumor size } \\
\text { in } 4^{\text {th }} \text { week }\end{array}$ & $\begin{array}{l}\text { Tumor size } \\
\text { in } 5^{\text {th }} \text { week }\end{array}$ & $\begin{array}{l}\text { Tumor size } \\
\text { in } 6^{\text {th }} \text { week }\end{array}$ & $\begin{array}{l}\text { Tumor size } \\
\text { before } \\
\text { dissection }\end{array}$ \\
\hline Mouse1 & $4 \times 10^{6}$ & $0.2 \mathrm{~cm}$ & $0.4 \mathrm{~cm}$ & $0.2 \mathrm{~cm}$ & $1.4 \mathrm{~cm}$ & $1.6 \mathrm{~cm}$ \\
\hline Mouse2 & $4 \times 10^{5}$ & $0.1 \mathrm{~cm}$ & $0.2 \mathrm{~cm}$ & $0.4 \mathrm{~cm}$ & $0.8 \mathrm{~cm}$ & $0.9 \mathrm{~cm}$ \\
\hline Mouse3 & $4 \times 10^{4}$ & 0 & 0 & $0.1 \mathrm{~cm}$ & $0.3 \mathrm{~cm}$ & $0.4 \mathrm{~cm}$ \\
\hline
\end{tabular}

Table3. The calculation of tumor volume.

\begin{tabular}{|l|l|l|l|l|l|}
\hline Nude & Tumor & Tumor volume in the & Tumor & Tumor volume after & Tumor \\
\hline
\end{tabular}




\begin{tabular}{|l|l|l|l|l|l|}
\hline mouse & $\begin{array}{l}\text { length(L) } \\
\text { in the } \\
\text { mouse } \\
\text { body }\end{array}$ & $\begin{array}{l}\text { mouse body } \\
\pi / 6 \times \mathrm{L} \times \mathrm{W} \times \mathrm{H})(\end{array}$ & $\begin{array}{l}\text { length(L) } \\
\text { after } \\
\text { dissection }\end{array}$ & $\begin{array}{l}\text { dissection } \\
\pi / 6 \times \mathrm{L} \times \mathrm{W} \times \mathrm{H})(\end{array}$ & $\begin{array}{l}\text { weight } \\
\text { after } \\
\text { dissectio } \\
\mathrm{n}\end{array}$ \\
\hline Mouse1 & $1.6 \mathrm{~cm}$ & $\begin{array}{l}\pi / 6 \times 1.6 \times 1.2 \times 1.5=1.44 \\
\mathrm{~cm}\end{array}$ & $2.1 \mathrm{~cm}$ & $\pi / 6 \times 2.1 \times 1.4 \times 1.8=2.65 \mathrm{~cm}$ & $1.9 \mathrm{gr}$ \\
\hline Mouse2 & $0.9 \mathrm{~cm}$ & $\begin{array}{l}\pi / 6 \times 0.9 \times 0.6 \times 0.8=0.22 \\
\mathrm{~cm}\end{array}$ & $1.0 \mathrm{~cm}$ & $\pi / 6 \times 1.0 \times 0.7 \times 0.8=0.28 \mathrm{~cm}$ & $0.37 \mathrm{gr}$ \\
\hline Mouse3 & $0.4 \mathrm{~cm}$ & $\begin{array}{l}\pi / 6 \times 0.4 \times 0.2 \times 0.3=0.01 \\
\mathrm{~cm}\end{array}$ & $0.5 \mathrm{~cm}$ & $\pi / 6 \times 0.5 \times 0.3 \times 0.4=0.03 \mathrm{~cm}$ & $0.1 \mathrm{gr}$ \\
\hline
\end{tabular}

\section{Discussion}

The laboratory mouse is the most common animal used to model cancer in vivo. The mouse small size and simple maintenance in addition to the physiological similarities to human have made it a useful system to model cancer of humans $(25,26)$. The xenograft tumor in nude mice is a useful model to study human tumors. The growth curves give us special data about human tumor biology in vivo. Furthermore, xenograft tumors can be used to study the effect of multiple agents like hormones, antibodies and so on, on tumor growth (24).

In the present study, we monitor the ability of cancer stem cells, isolated with sphere formation assay, to form xenograft tumors in nude mice. We used three different cell dilations which all made measurable tumors. The tumors in the first and the second mice were measurable three weeks after injection but the third mouse had a measurable tumor since 5th week. The size of tumors was appropriate to the number of cells injected and the minimum cell number required for tumor formation in our study was $4 \times 104$ cells. The Matrigel used in the mixture of injection leads the tumor cells concentrate in the injection site and prevents the cells from spreading around, so it results in the formation of a uniform tumor and makes it easy to measure the size of the tumor. It is noted that Matrigel must be kept on ice at the time of injection because it transforms into a gel-like state in room temperature which makes it difficult to inject the cells. So it is better to prepare the cells in micro tubes after cell counting and inject them immediately after Matrigel addition to the mixture of cells in PBS.

\section{Conclusion}

Modeling human cancers using mouse models is a functional method which gives us the possibility to simulate and study human cancer in vivo. In our study YM1 cancer stem-like cells enriched by sphere formation assay were able to make subcutaneous tumors in nude mouse models.

\section{Acknowledgements}

This study was extracted from a Ph.D. thesis supported by the Golestan University of Medical Sciences (research grant no 920723102).

\section{Declarations}

\section{Ethics approvals and consent to participate}

This study was approved by the ethical committee of Golestan University of Medical Sciences.

\section{Conflict of interest}

There are no conflicts to declare 


\section{References}

1. Nault Jc, Bioulac-Sage P, Zucman-Rossi J. Reviews In Basic And Clinical gastroenterology and hepatology. Gastroenterology. 2013;144:888902. [DOI:10.1053/j.gastro.2013.02.032]

2. Ingelfinger JR, Rustgi A, El-Serag $\mathrm{H}$. Esophageal carcinoma. N Engl J Med. 2014;371:2499-509.

\section{[DOI:10.1056/NEJMra1314530]}

3. Kamangar F, Dores GM, Anderson WF. Patterns of cancer incidence, mortality, and prevalence across five continents: defining priorities to reduce cancer disparities in different geographic regions of the world. Journal of clinical oncology. 2006;24(14):2137-50. [DOI: 10.1200/JCO.2005.05.2308]

4. Enzinger PC, Ilson DH, Kelsen DP. Chemotherapy in esophageal cancer. Seminars in oncology. 1999;26(5 Suppl 15):12-20.

5. Pennathur A, Farkas A, Krasinskas AM, Ferson PF, Gooding WE, Gibson MK, et al. Esophagectomy for T1 esophageal cancer: outcomes in 100 patients and implications for endoscopic therapy. The Annals of thoracic surgery. 2009;87(4):1048-55.

[DOI:10.1016/j.athoracsur.2008.12.060]

6. Shultz LD, Goodwin N, Ishikawa F, Hosur V, Lyons BL, Greiner DL. Human cancer growth and therapy in NOD/SCID/IL2R $\gamma$ null (NSG) mice. Cold Spring Harbor protocols. 2014;2014(7):694. [DOI:10.1101/pdb.top073585]

7. Saxena M, Christofori G. Rebuilding cancer metastasis in the mouse. Molecular oncology. 2013;7(2):283-96.

[DOI:10.1016/j.molonc.2013.02.009]

8. Berghmans S, Jette C, Langenau D, Hsu K, Stewart R, Look T, et al. Making waves in cancer research: new models in the zebrafish. Biotechniques. 2005;39(2):227-37.
9. Khanna C, Hunter K. Modeling metastasis in vivo. Carcinogenesis. 2005;26(3):513-23. [DOI:10.1093/carcin/bgh261]

10. Blouin S, Baslé MF, Chappard D. Rat models of bone metastases. Clinical \& experimental metastasis.

2005;22(8):605.

[DOI:10.1007/s 10585-006-9002-5]

11. Niu H-x, Du T, Xu Z-f, Zhang X-k, Wang Rg. Role of wild type p53 and double suicide genes in interventional therapy of liver cancer in rabbits. Acta cirurgica brasileira. 2012;27(8):522-8. [DOI:10.1590/S0102-86502012000800002]

12. Hubbard G, Wood D, Butcher W. Mammary carcinoma with metastasis in a rhesus monkey (Macaca mulatta). Veterinary pathology. 1984;21(5):531-3.

[DOI:10.1177/030098588402100515]

13. Fantozzi A, Christofori G. Mouse models of breast cancer metastasis. Breast Cancer Research. 2006;8(4):212. [DOI:10.1186/bcr1530]

14. Lapidot T, Sirard C, Vormoor J, Murdoch B, Hoang T, Caceres-Cortes J, et al. A cell initiating human acute myeloid leukaemia after transplantation into SCID mice. nature. 1994;367(6464):645. [DOI:10.1038/367645a0]

15. Al-Hajj M, Wicha MS, Benito-Hernandez A, Morrison SJ, Clarke MF. Prospective identification of tumorigenic breast cancer cells. Proceedings of the National Academy of Sciences. 2003;100(7):3983-8. [DOI:10.1073/pnas.0530291100]

16. Singh SK, Hawkins C, Clarke ID, Squire JA, Bayani J, Hide T, et al. Identification of human brain tumour initiating cells. nature. 2004;432(7015):396. [DOI:10.1038/nature03128]

17. Dalerba P, Dylla SJ, Park I-K, Liu R, Wang $\mathrm{X}$, Cho RW, et al. Phenotypic characterization of human colorectal cancer stem cells. Proceedings of the National Academy of Sciences. 2007;104(24):10158-63.

[DOI:10.1073/pnas.0703478104]

[DOI: 10.2144/05392RV02] 
18. Zhang S, Balch C, Chan MW, Lai H-C, Matei D, Schilder JM, et al. Identification and characterization of ovarian cancer-initiating cells from primary human tumors. Cancer research. 2008;68(11):4311-20.

[DOI:10.1158/00085472.CAN-08-0364]

19. Hermann PC, Huber SL, Herrler T, Aicher A, Ellwart JW, Guba M, et al. Distinct populations of cancer stem cells determine tumor growth and metastatic activity in human pancreatic cancer. Cell stem cell. 2007;1(3):313-23. [DOI:10.1016/j.stem.2007.06.002]

20. Shiozawa Y, Nie B, Pienta KJ, Morgan TM, Taichman RS. Cancer stem cells and their role in metastasis. Pharmacology \& therapeutics. 2013;138(2):285-93.

\section{[DOI:10.1016/j.pharmthera.2013.01.014]}

21. Pastrana E, Silva-Vargas V, Doetsch F. Eyes wide open: a critical review of sphere-formation as an assay for stem cells. Cell stem cell. 2011;8(5):486-98.

\section{[DOI:10.1016/j.stem.2011.04.007]}

22. Chen Y-C, Ingram PN, Fouladdel $\mathrm{S}$, McDermott SP, Azizi E, Wicha MS, et al. Highthroughput single-cell derived sphere formation for cancer stem-like cell identification and analysis. Scientific reports. 2016;6:27301. [DOI:10.1038/srep27301]

23. Ayyoob K, Masoud K, Vahideh K, Jahanbakhsh A. Authentication of newly established human esophageal squamous cell carcinoma cell line (YM-1) using short tandem repeat (STR) profiling method. Tumor Biology. 2016;37(3):3197-204. [DOI:10.1007/s13277-0154133-4]

24. Tomayko MM, Reynolds CP. Determination of subcutaneous tumor size in athymic (nude) mice. Cancer chemotherapy and pharmacology. 1989;24(3):148-54. [DOI:10.1007/BF00300234]

25. Frese KK, Tuveson DA. Maximizing mouse cancer models. Nature Reviews Cancer. 2007;7(9):654. [DOI:10.1038/nrc2192]

26. Maddison K, Clarke AR. New approaches for modelling cancer mechanisms in the mouse. The Journal of Pathology: A Journal of the Pathological Society of Great Britain and Ireland. 2005;205(2):181-93. [DOI:10.1002/path.1698]

\section{How to cite:}

Khosravi A, Kokabi F, Behzadi R, Jahanbakhsh Asadi. Tumorigenicity of Esophageal Cancer Stem Cells (ECSCs) in nude mouse xenograft model. Jorjani Biomedicine Journal. 2019; 7(3): 4-10. 